See discussions, stats, and author profiles for this publication at: https://www.researchgate.net/publication/229324995

\title{
Consensus on Criteria for Potential Areas for Wolf Reintroduction in Mexico
}

Article in Conservation Biology · August 2012

DOI: 10.1111/j.1523-1739.2012.01888.x · Source: PubMed

CITATIONS

13

9 authors, including:

Luis Carrillo

4 PUBLICATIONS 21 CITATIONS

SEE PROFILE

Enrique Martínez-Meyer

Universidad Nacional Autónoma de México

169 PUBLICATIONS 7,953 CITATIONS

SEE PROFILE

Some of the authors of this publication are also working on these related projects:

Project Ecología de mamíferos de la Península de Yucatán View project

Project Currently working on reintroducing Mexican wolves to Northern Mexico. View project
READS

292

Rurik List

Metropolitan Autonomous University

75 PUBLICATIONS 1,175 CITATIONS

SEE PROFILE 


\title{
Consensus on Criteria for Potential Areas for Wolf Reintroduction in Mexico
}

\author{
MARCELA ARAIZA, ${ }^{*}$ LUIS CARRILLO,†\\RURIK LIST, $¥ \uparrow \uparrow$ CARLOS A. LÓPEZ GONZÁLEZ,』 \\ ENRIQUE MARTÍNEZ MEYER, $\uparrow$ PATRICIA G. MARTÍNEZ-GUTIÉRREZ, ${ }^{* * *}{ }^{*}$ OSCAR \\ MOCTEZUMA, ${ }^{* *}$ NAHUM E. SÁNCHEZ-MORALES, †† AND JORGE SERVÍN
}

\begin{abstract}
* Programa Regional de Manejo de Vida Silvestre, Universidad Nacional, Apartado 1350, Heredia 3000, Costa Rica †Conservation Breeding Specialist Group México, 11 Oriente 2407, Col. Azcárate, Puebla, Mexico ‡Instituto de Ecología, Universidad Nacional Autónoma de México, 3er Circuito Exterior Ciudad Universitaria, Coyoacán, Mexico, D.F. 04510, Mexico

§Universidad Autónoma de Querétaro, Cerro de las Campanas S/N, Col. Las Campanas. Queretaro, Queretaro 76010, Mexico ๆInstituto de Biología, Universidad Nacional Autónoma de México, 3er Circuito Exterior Ciudad Universitaria, Coyoacán, Mexico, D.F. 04510, Mexico

**Naturalia A.C., Calle 19 \#69, Col. San Pedro de los Pinos, Mexico, D.F. 03800, Mexico ††Tierra Silvestre A. C., Calle de la Cañada 618, Col. La Lomas Sector Jardines, Garcia, Nuevo León 66024, Mexico $\ddagger \ddagger U$ Universidad Juarez del Estado de Durango, Instituto de Ciencias Sociales, Depto. Desarrollo Sustentable, Privada de Aquiles Serdán y Predio Canoas S/N, Col. Los Ángeles, Durango, Durango 34000, Mexico
\end{abstract}

\begin{abstract}
Given the conflict with human interests that in many cases results in the extirpation of large carnivores, acceptance of their reintroduction is a considerable challenge. By the 1980s Mexican wolves (Canis lupus) were extinct in the wild. In 1998 a population was reintroduced in the Blue Range Mountains of New Mexico (U.S.A.). Efforts to reintroduce the species in Mexico bave been ongoing since the late 1980s. Four teams working independently identified 6 areas in northern Mexico in the bistoric range of Mexican wolves, where reintroductions could potentially be successful. Each team used different methods and criteria to identify the areas, which makes it difficult to prioritize among these areas. Therefore, members of the different teams worked together to devise criteria for use in identifying priority areas. They identified areas with high, intermediate, and low potential levels of conflict between wolves and humans. Areas with low potential conflict had larger buffers (i.e., distance from buman settlement to areas suitable for wolves) around buman settlements than high-and intermediate-conflict areas and thus were thought most appropriate for the first reintroduction. High-conflict areas contained habitat associated with wolf presence, but were closer to buman activity. The first reintroduction of Mexican wolves to Mexico occurred in October 2011 in one of the identified low-conflict areas. The identification of suitable areas for reintroduction represents a crucial step in the process toward the restoration of large carnivores. Choice of the first reintroduction area can determine whether the reintroduction is successful or fails. A failure may preclude future reintroduction efforts in a region or country.
\end{abstract}

Keywords: Canis lupus bailely, large carnivore, Mexican wolf, prioritization, species reintroduction

Consenso en Criterios para Áreas Potenciales para la Reintroducción de Lobos en México

Resumen: Debido al conflicto con intereses bumanos que en muchos casos resulta en la extirpación de carnívoros mayores, la aceptación de su reintroducción es un reto considerable. En la década de 1980 los

\footnotetext{
ISCurrent address: Zoofari. Km. 55 Carretera Federal Cuernavaca Taxco, Teacalco, Morelos, Mexico.

ฯAAdress correspondence to R. List, CBS Universidad Autonoma Metropolitana-Lerma, Hidalgo Pte. 46, Col. La Estación, Lerma, Estado de México, 52006, México, email r.list@correo.ler.uam.mx

***Current address: Department of Conservation Biology, Estacion Biologica de Doñana, Consejo Superior de Investigaciones Científicas, Avenida de María Luisa s/n, 41092, Sevilla, Spain.

†††Current address: Universidad Autónoma Metropolitana-Xochimilco, Departamento del Hombre y Su Ambiente, Calzada del Hueso 1100 , Col. Villa Quietud, Delegación Coyoacán, D.F, 04960, Mexico.

Paper submitted March 3, 2011; revised manuscript accepted March 2, 2012.
} 
lobos mexicanos (Canis lupus) estaban extintos en vida libre. En 1998 una población fue reintroducida en las Montañas Blue Range, Nuevo México (E.U.A.). Los esfuerzos para reintroducir la especie en México ban sido continuos desde fines de la década de 1980. Cuatro equipos trabajando independientemente identificaron 6 áreas en el norte de México en el rango de distribución bistórico de lobos mexicanos, en los que la reintroducción potencialmente tendría éxito. Cada equipo utilizó diferentes métodos y criterios para identificar las áreas, lo cual dificulta la priorización de estas áreas. Por lo tanto, integrantes de los diferentes equipos trabajaron conjuntamente para diseñar criterios para la identificación de áreas prioritarias. Identificaron áreas con alto, intermedio y bajo nivel de conflicto entre lobos y bumanos. Las áreas con bajo potencial de conflicto tenían mayores zonas de amortiguamiento (i.e., distancia entre asentamientos bumanos y áreas adecuadas para lobos) alrededor de los asentamientos bumanos que las áreas con niveles altos e intermedios de conflicto y por lo tanto se pensó que eran más apropiadas para la primera reintroducción. Las áreas con nivel de conflicto alto contenían hábitat asociado con la presencia de lobos, pero estaban cerca de actividades bumanas. La primera reintroducción de lobo mexicano en México se llevó a cabo en octubre de 2011 en uno de los sitios identificados con nivel de conflicto bajo. La identificación de áreas adecuadas para la reintroducción representa un paso crucial en el proceso bacia la restauración de carnívoros mayores. La elección del área de la primera reintroducción puede determinar si la reintroducción es exitosa o fracasa. Un fracaso puede impedir futuros esfuerzos de reintroducción en una región o país.

Palabras Clave: Canis lupus bailely, lobo mexicano, priorización, reintroducción de especies

\section{Introduction}

Ecosystem structure and function have been reported to vary after either the extirpation or reintroduction of wolves (Canis lupus). For example, wolf populations limit abundance of coyotes (Canis latrans) (Fuller \& Keith 1981; Carbyn 1982; Crabtree \& Sheldon 1999), and absence of wolves may have contributed to the southward and eastward expansion of coyotes in Canada and the United States (Gier 1975; Nowak 1978; Dekker 1989). Wolf extirpation has also been linked to changes in vegetation composition and structure (McLaren \& Peterson 1994; Ripple \& Larsen 2000) and changes in abundance and species richness of other animals (Berger et al. 2001; Hebblewhite et al. 2005). Furthermore, after the reintroduction of wolves in Yellowstone, ungulate behavior changed (Laundré et al. 2001; Ripple et al. 2001) and vegetation is recovering from intensive grazing by ungulates (Ripple \& Beschta 2003). Accordingly, restoration of ecosystems is being used as an argument for the restoration of carnivores, including wolves, to ecologically functional densities and distributions (Parsons 2003; Ripple \& Beschta 2003; Soulé et al. 2003; Soulé et al. 2005).

The role of the wolf in Mexican landscapes has not been studied. The riparian areas of northern Mexico have been heavily grazed and degraded by cattle, and wolves are likely to use these areas, especially in the relatively dry Sierra Madre Occidental. The presence of wolves in riparian areas could change native and domestic ungulate behavior and reduce their level of use of these areas (e.g., Brown et al. 1999; Laundré et al. 2001; Hernández \& Laundré 2005; Beschta \& Ripple 2010).

The Mexican wolf (Canis lupus baileyi) is the most distinct subspecies in North America (Nowak 1983; Moreno et al. 1996). Originally, it was distributed from the southwestern United States to central Mexico (Leopold 1959;
Hall 1980), but by the 1980s it was considered extinct in the wild (McBride 1980; Brown 1992; Secretaría del Medio Ambiente y Recursos Naturales 2010). In 1978 a binational captive-breeding program was launched to prevent the extinction of the subspecies (Ames 1982; Bernal Stoopen et al. 2009). Public interest in the reintroduction of the wolf in Mexico started in 1989, when a group of individuals and organizations started working collaboratively toward that goal. In 2000 the group became an advisory entity to the Mexican Ministry of the Environment (Secretaría del Medio Ambiente y Recursos Naturales [SEMARNAT]) as the Consultative Subcommittee for the Recovery of The Mexican Wolf (Comité Consultivo para la Recuperación del Lobo Mexicano).

From 2000 until 2005, 4 research teams conducted independent studies to identify potential areas for wolf reintroduction in Mexico. The teams used different criteria and approaches and identified 6 areas for reintroduction, 4 in the Sierra Madre Occidental (northwestern Mexico), and 2 in the Sierra Madre Oriental (northeastern Mexico). Araiza (2001), Caroll et al. (2006), Sánchez and Guevara (2006), and Martínez-Gutiérrez (2007) evaluated northern Mexico. Only Martínez-Gutiérrez (2007) considered the full historic range of the wolf in Mexico.

In April 2006, the Consultative Subcommittee organized the Mexican Wolf (Canis lupus baileyi) Reintroduction Workshop. Thirty people from Mexico and the United States participated in this experts' workshop. The goals of the workshop were to identify the most suitable areas for reintroduction in Mexico and to develop a release protocol that would profit from the experience gained from wolf reintroductions in the United States (Araiza et al. 2007). The areas identified by each team were presented to the experts. However, each team used different methods and examined different spatial extents, so it was not possible to reach a consensus on 
prioritization of different areas for reintroduction. Thus, reintroduction plans slowed down because it was difficult to agree on an area where efforts and funding should be focused. The primary conclusion of the experts at the workshop was that there is a need to unify and refine the criteria and methods used to identify potential areas for reintroduction of the Mexican wolf and that the criteria should include a consensus on habitat quality and probability of anthropogenic mortality. Our goal was to generate such consensus on the criteria and methods with respect to the already identified potential regions for wolf reintroduction in Mexico.

\section{Methods}

We conducted a spatial analysis of each of the 6 regions potentially suitable for wolf reintroduction (Fig. 1). We identified and quantified the area of potential habitat on the basis of museum and literature records for wolves in Mexico. For our purposes and the scale of analyses, the number of records of wolves in different vegetation types and distance to human-populated places and roads were indications of high, intermediate, and low habitat quality. First, we evaluated wolf associations with vegetation types by spatially overlaying 264 occurrence records on a map of potential primary vegetation (pine forest, pine-oak forest, oak forest, oak-pine forest, grasslands, Douglas fir [Pseudotsuga menziesii]-spruce forest, mesquite shrubland, fir forest, desert shrubland, subtropical thorn scrub) produced by the National Institute of Geography and Statistics between 1999 and 2000 (INEGI 2003). Occurrence data came from 219 interviews with elders who provided data from 1915 to the $1970 \mathrm{~s}$ (J.S., unpublished data), 30 records from the literature, and 29 museum specimens (Martínez-Gutiérrez 2007). We used the 1999-2000 map of potential primary vegetation rather than a current land-cover map because we did not have information on the degree of land-cover change at the time the wolves were recorded and because we believed it was reasonable to assume that the extent of natural vegetation and intensity of land use were less in the past than today (Lammertink et al. 1997; INEGI 2003; Martínez-Gutiérrez 2007) (Table 1). Historically, wolves likely had stronger associations with open vegetation types such as grasslands. Today, these areas are grazed by cattle and the resulting potential for conflict with humans makes them less suitable for wolves.

To determine the type of vegetation associated with wolf occurrences within their historical range in Mexico, we determined the proportion of wolf occurrences (use) in each primary vegetation type and the proportion of each potential primary vegetation type within that range. We tested the null hypothesis that the wolves used the vegetation types in proportion to the amount available with a chi-square test. We calculated Bonferroni confidence intervals $(\alpha=0.05)$ to evaluate whether the expected use of each vegetation type was significantly different from actual use (Neu et al. 1974; Byers et al. 1984) (Table 1).

We identified patches of habitat for the Mexican wolf within its historical range on a map of current vegetation (Instituto de Geografía 2001). We classified the quality of vegetation types in these patches from 1 (highest quality) to 6 (lowest quality) on the basis of results of the vegetation-association analysis and the current status of land-cover transformation. For example, an area of a given vegetation type that was unaffected by human activity would be more suitable than an area where primary and secondary (i.e., affected by human activity) vegetation types were mixed.

On the basis of human population size, we delineated circular buffer areas around populated areas within a geographic information system (GIS). Buffer area was the distance between human settlement and areas considered suitable for wolves. Human settlements are represented as points in our source data (INEGI 2002) regardless of their population size. The width of the buffer increased as human population size increased and was up to 4500 $\mathrm{m}$ for settlements with $>15,000$ people (Table 2 ). For example, we assumed that an area would be unsuitable for wolves (i.e., high probability of human-caused mortality) if it were within $1000 \mathrm{~m}$ of a human settlement with 1-20 inhabitants, which is the distance at which wolves avoid buildings (Kaartinen et al. 2005), and that wolves would have low probability of mortality if they were within $5000 \mathrm{~m}$ of a human settlement of that size. The minimum and maximum distances for the intermediate probability of mortality, depending on size of the human population, were 2500 and $6000 \mathrm{~m}$, respectively. The maximum distance for low probability of mortality was $12,000 \mathrm{~m}$ (Table 2). We followed a similar approach to buffer areas around roads, which are represented as single lines in our source data (INEGI 2000). At the high probability of mortality, buffers along roads extended $250 \mathrm{~m}$ on each side, the distance at which wolves avoid roads (Kaartinen et al. 2005). At the intermediate and low probabilities of mortality, buffers along roads extended on each side 500 and $750 \mathrm{~m}$, respectively.

We combined the maps of vegetation associated with wolf occurrence, buffer areas around settlements, and buffer areas around roads to identify the largest patches (i.e., contiguous polygons of the same or different vegetation type) of the highest habitat quality to prioritize areas for potential reintroduction and to identify where prey availability and potential social attitudes toward wolf reintroduction should be assessed. We assumed that potential release patches were those with habitat qualities of 1 and 2 that were $>150 \mathrm{~km}^{2}$, which is the smallest home range of a wolf pack in Arizona (Arizona Game and Fish Department et al. 2008). 


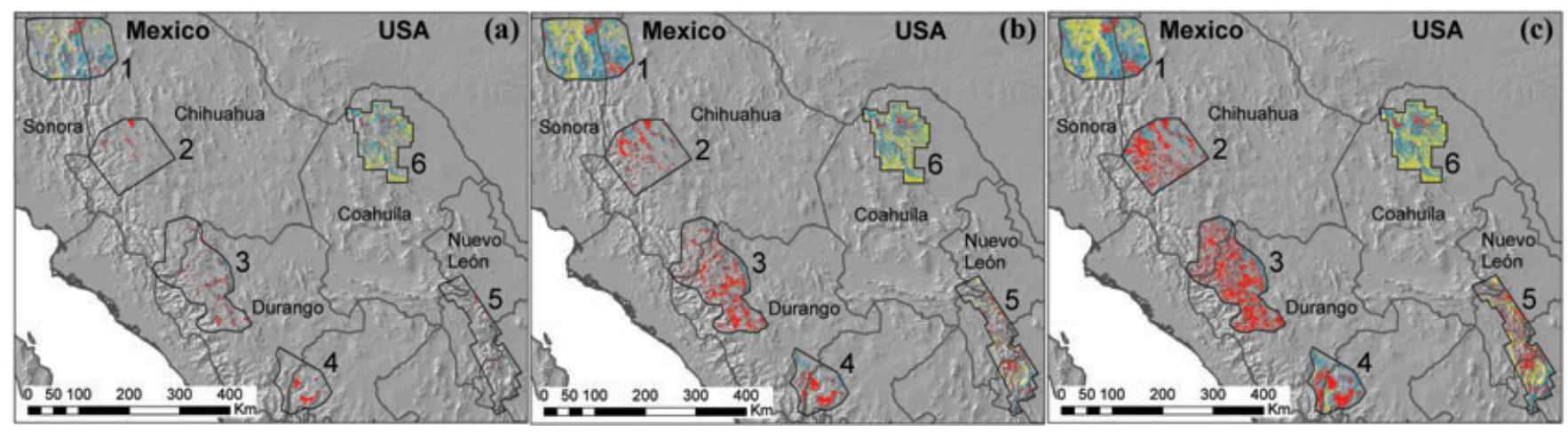

Figure 1. Patches of Mexican wolf habitat within potential reintroduction areas in nortbern Mexico (1, Sonora-Chibuabua; 2, Central Chibuabua; 3, Chibuabua-Durango; 4, Durango-Zacatecas; 5, Nuevo León-Tamaulipas; 6, Coabuila): (a) areas where wolves have a low probability of antbropogenic mortality, (b) areas where probability of anthropogenic mortality is intermediate, and (c) areas where probability of antbropogenic mortality is bigh (light red, patches of bigh babitat quality [categories 1 and 2, Table 1] >150 km ; dark red, patches of bigh babitat quality [categories 1 and 2$]<150 \mathrm{~km}^{2}$; blue, patches of intermediate babitat quality (categories 3 and 4); yellow, patches of low babitat quality (categories 5 and 6)).

\section{Results}

Results of the habitat-association analyses indicated wolf occurrences were not proportional to the area of vegetation types $\left(\chi^{2}=13651.96, \mathrm{df}=10, p<0.001\right)$. A greater proportion of occurrences were associated with pine forest, pine-oak forest, and oak-pine forest than expected. Occurrences in oak forest, fir forest, and mesquite shrubland were proportional to the relative area of these vegetation types, whereas there were a lower proportion of occurrences in native grasslands, desert shrubland, and subtropical thorn scrub than expected (Table 1). Thus, on the basis of these results and the current vegetation (considering transformation) within the area historically occupied by the wolf, the order, from highest to lowest habitat quality, of vegetation types was pine forest and pine-oak forest; pine forest and pine-oak forest with secondary vegetation; oak forest, fir forest, and mesquite shrubland; oak forest, fir forest, and mesquite shrubland with secondary vegetation; desert shrubland and subtropical thorn scrub; desert shrubland and subtropical thorn scrub with secondary vegetation; and native grasslands (Table 3). Native grasslands were classified as of the lowest quality because these are open areas where wolves would be highly visible to humans and therefore more likely to be killed.

Table 1. Bonferroni confidence intervals of historic wolf-vegetation associations in Mexico derived from a map of potential primary vegetation (INEGI 2003) and proportion of historical records.

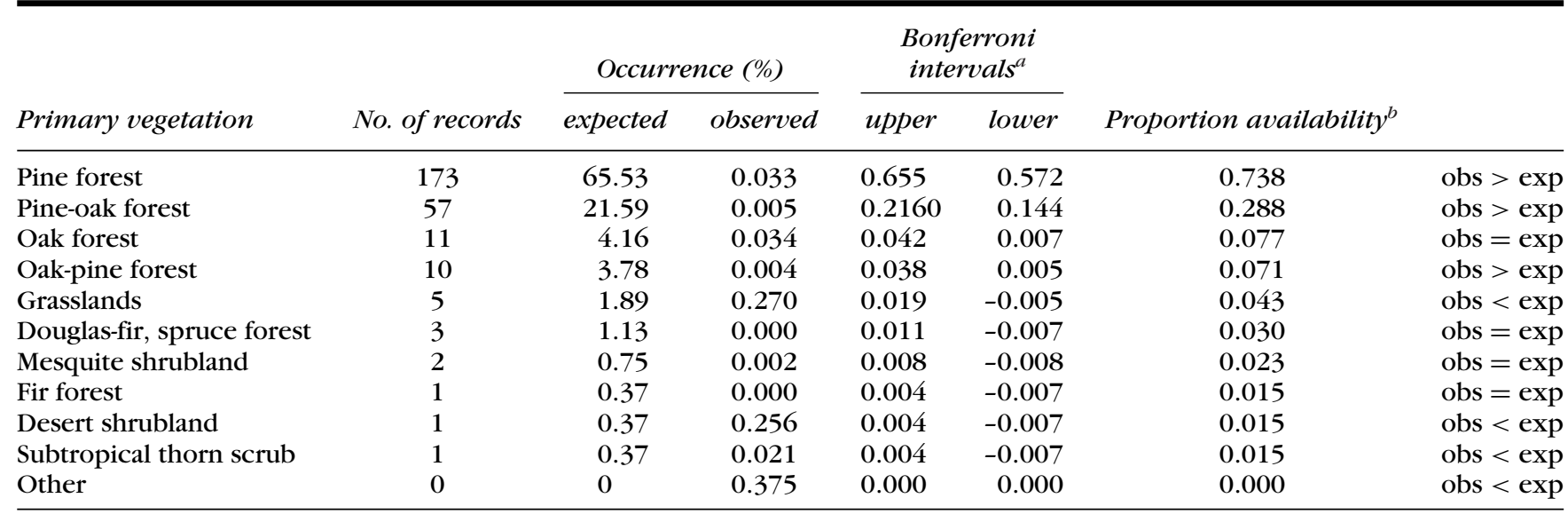

Note: Historical records from interviews with elders who provided data from 1915 through the 1970 , the literature, and museum specimens.

${ }^{a}$ An expected proportion smaller than the interval indicates the number of records of wolves in the vegetation type was greater than expected if the proportion of records was equal to the proportional cover of each vegetation type; an expected proportion larger than the interval indicates the number of records of wolves in the vegetation type was smaller than expected. When the expected proportion lies within the interval, we assumed the number of records in the vegetation type was expected (Neu et al. 1974; Byers et al. 1984).

${ }^{b}$ Abbreviations: obs, proportion of observed records; exp, proportion of expected records. 
Table 2. Habitat quality of different vegetation types for the Mexican wolf.

\begin{tabular}{lc}
\hline Vegetation type $^{\mathrm{a}}$ & Quality $^{b}$ \\
\hline Pine forest & 1 \\
Pine-oak forest & 1 \\
Pine forest with secondary vegetation & 2 \\
Pine-oak forest with secondary vegetation & 2 \\
Oak forest & 3 \\
Fir forest & 3 \\
Mesquite shrubland & 3 \\
Oak forest with secondary vegetation & 4 \\
Fir forest with secondary vegetation & 4 \\
Mesquite shrubland with secondary vegetation & 4 \\
Desert shrubland & 5 \\
Subtropical shrubland & 5 \\
Subtropical shrubland with secondary vegetation & 6 \\
Desert shrubland with secondary vegetation & 6 \\
Grasslands & 6 \\
\hline
\end{tabular}

${ }^{\mathrm{a}}$ Classified on the basis of potential primary vegetation types (INEGI 2003) and current vegetation types in Mexico (Instituto de Geografia 2001). Secondary vegetation means forests or vegetation established naturally after a dramatic disturbance (e.g., clearcutting); secondary species account for more than $70 \%$ of the vegetation cover.

${ }^{b}$ Habitat quality decreases as numbers increase: (1) observed proportion of records of wolves greater than expected if the proportion of records was equal to the proportion cover of the vegetation type within the study area (highest habitat quality); (2) observed proportion greater than expected with secondary vegetation; (3) observed proportion equal to expected frequency; (4) observed proportion equal to expected with secondary vegetation; (5) observed proportion lower than expected; (6) observed proportion lower than expected frequency with secondary vegetation (lowest habitat quality).

Prioritization of areas for reintroduction differed at different probabilities of anthropogenic mortality. Participants in the experts' workshop agreed that areas $>10,000$ $\mathrm{km}^{2}$ should be considered suitable for reintroduction; however, no single habitat patch in the 6 areas participants considered was $>10,000 \mathrm{~km}^{2}$ (Fig. 1). The largest patch with low probability of mortality was $354 \mathrm{~km}^{2}$ along the northern boundary of the states of Sonora and Chihuahua (Sonora-Chihuahua area); the largest patch with intermediate probability of mortality was $877 \mathrm{~km}^{2}$ along the boundary of the states of Durango and Chihuahua (Chihuahua-Durango area); and the largest patch with high probability of mortality was $1636 \mathrm{~km}^{2}$ in the Chihuahua-Durango area. The largest clusters of habitat patches were in the Sonora-Chihuahua area. Sizes of these clusters assigned low, intermediate, and high probabilities of mortality were $7,828,15,705$, and 20,716 $\mathrm{km}^{2}$, respectively (Fig. 1). The largest cluster of patches with habitat quality 1 or 2 was in the Chihuahua-Durango area. In this cluster, areas of $2,175,8,344$, and $15,308 \mathrm{~km}^{2}$ were assigned low, intermediate, and high probabilities of mortality, respectively (Fig. 1).

\section{Discussion}

There are 2 extremes to the options available for the prioritization of potential reintroduction areas. Reintro-
Table 3. Width of buffer around center of human settlements in potential areas for wolf reintroduction with high, intermediate, and low probabilities of anthropogenic mortality.

\begin{tabular}{lccc}
\hline \multirow{2}{*}{$\begin{array}{c}\text { Number of } \\
\text { people }\end{array}$} & $\begin{array}{c}\text { Buffer width (km) } \\
\text { probability }\end{array}$ & $\begin{array}{c}\text { intermediate } \\
\text { probability }\end{array}$ & $\begin{array}{c}\text { bigh } \\
\text { probability }\end{array}$ \\
\cline { 2 - 4 } $1-20$ & 5 & 2.5 & 1 \\
$21-100$ & 6 & 3 & 1.5 \\
$101-500$ & 7 & 3.5 & 2 \\
$501-1500$ & 8 & 4 & 2.5 \\
$1501-3000$ & 9 & 4.5 & 3 \\
$3001-7500$ & 10 & 5 & 3.5 \\
$7,501-15,000$ & 11 & 5.5 & 4 \\
$15,001-25,000$ & 12 & 6 & 4.5 \\
\hline
\end{tabular}

Note: Area of increased mortality risk, defined as the distance between a buman settlement at the center of a circle and the area considered as suitable for reintroduction at the periphery of the circle

duction areas where the probability of anthropogenic wolf mortality is low are relatively small and few; thus, relatively fewer wolf populations can potentially be established in these areas. However, there is an increased possibility of survival in such areas given their greater distance from roads and human settlements. Reintroduction areas where the probability of mortality is high are relatively close to roads and human settlements, but the potential reintroduction area and thus the potential size of the wolf population is larger.

Priority areas for reintroduction identified on the basis of all habitat patches regardless of habitat quality were very different from priority areas identified only on the basis of different probabilities of mortality. When we considered all habitat patches, the Sonora-Chihuahua area was of the highest priority for reintroduction. This area included the largest habitat patch of quality 1 or 2 (Fig. 1). Use of only habitat patches with intermediate probability of mortality did not add new priority areas or change the ranking of areas with the high and low probabilities of mortality.

Therefore, it was unclear whether criteria that we based on all vegetation types in which wolves occurred or only the types with the highest proportion of occurrences (habitat quality 1 and 2) would lead to identification of areas where the probability of reintroduction success would be higher. In Italy and Spain, wolves use areas in close proximity to human settlements, enter villages, and feed at garbage dumps (Boitani 1983; Ciucci et al. 1996). Therefore, by choosing the Chihuahua-Durango area-the largest area with highest quality habitat-we would expect a larger recovery area and hence a larger wolf population to be established. However, it would be advisable to conduct the first reintroduction effort in the Sonora-Chihuahua area because wolves tend to avoid roads (Kaartinen et al. 2005; Whittington et al. 2005) and humans have been the leading cause of deaths of 
Mexican wolves reintroduced to Arizona (Paquet et al. 2001; Arizona Game and Fish Department 2009). Survival and reproduction of the released individuals is more important than the potential for expansion across the landscape because the latter is contingent upon the former. Although the interaction of environmental and anthropogenic factors with physiography may affect the quality of wolf habitat, in Mexico such interaction resulted from historical human actions within the geographic distribution of Mexican wolves. Mexican wolves persisted longer in rugged to very rugged habitat, where predator control was more difficult and hence less intense (Molina Bravo 1964; Brown 1992).

Releasing wolves far from roads and human settlements may also reduce the potential for disease transmission from domestic dogs. The level of inbreeding in the captive population may have made these wolves more susceptible to pathogens. Several young from the reintroduction program recaptured in Arizona died of canine parvovirus or canine distemper. It is suspected that contact with domestic dogs from towns in the area was the source of the disease (Hedrick et al. 2003). Canine parvovirus and distemper are commonly present in coyotes, foxes, and domestic dogs in the region (Araiza 2001).

Subsequently and independent of this study, another workshop with the wolf specialists, coordinated by SEMARNAT, determined methods to assess prey availability and perception of local people toward wolves and a potential reintroduction. Prey densities were estimated with camera-traps and perceptions evaluated with questionnaires. These assessments were done simultaneously in the 6 areas. Results showed that both the Sonora-Chihuahua and Chihuahua-Durango regions contain sufficient prey to sustain wolves, and perception toward wolves was such that with adequate education and attention to the concerns of stakeholders, a reintroduction may be possible (Subcomité Técnico Consultivo para la Recuperación del Lobo Mexicano et al. 2009). On the basis of this information, SEMARNAT will conduct the first reintroduction in the Sonora-Chihuahua region and use the Chihuahua-Durango region as a secondary reintroduction area conditioned on the identification of a wolf-like canid documented with a camera trap during the prey-abundance survey (J.S., unpublished data).

Male coyotes have been reported to breed with female gray wolves in areas with high coyote and low wolf densities (Lehman et al. 1991; Roy et al. 1994). Hybridization with coyotes is a major threat to a reintroduced red wolf (Canis rufus) population (Kelly et al. 1999; Adams et al. 2007; Hedrick \& Fredrickson 2008). Domestic dogs ( $\mathrm{Ca}$ nis familiaris) have also been reported to breed with gray wolves and Ethiopian wolves (Canis simensis) in the wild (e.g., Randi \& Lucchini 2002; Vilà et al. 2003; Verardi et al. 2006). Because of the risk of genetic extinction of Mexican wolves through hybridization (Rhymer \& Simberloff 1996; Adams et al. 2003), before consider- ing a reintroduction in the Chihuahua-Durango region, we suggest the genetic identity of the wolf-like canid be documented. Although the objective of the present work was to determine where wolves should be reintroduced to increase the probability of establishing a wolf population, the areas we identified as suitable but less than ideal could be considered for later reintroductions as expertise is gained from the initial reintroduction, financial resources increase, and work is conducted to improve the habitat quality of the sites.

At the time of writing, attempts to trap or obtain fecal samples for genetic analyses of the wolf-like canid in the Chihuahua-Durango area had been unsuccessful, but a family group composed of an older female and 4 offspring from 2 separate litters was released in the Sonora-Chihuahua region on 11 October 2011. About 2 months later, one wolf was found dead close to a dirt road, and 3 others were found dead on a ranch in the Chihuahua side of the release region. Two of these wolves proved to have been poisoned. It is unknown whether they ingested poison intended for other carnivores or whether they were the targets. All wolves had satellite and VHF collars. This allowed the field workers to follow their movements, confirm that no livestock predation events took place since the reintroduction, and determine that they had been feeding on native prey (Naturalia 2012). The surviving female separated from the rest of the pack shortly after the reintroduction (Naturalia, unpublished data). There are plans to continue the release of wolves within this area in 2012. The monitoring of reintroduced individuals will continue.

\section{Acknowledgments}

Funding for fieldwork was provided by the Comisión Nacional de Áreas Naturales Protegidas through the Comisión Nacional Para el Conocimiento y Uso de la Biodiversidad and Defenders of Wildlife. Three anonymous reviewers, E. Fleishman, and M. Main provided valuable comments to improve the manuscript.

\section{Literature Cited}

Adams, J. R., C. Lucash, L. Schutte, and L. P. Waits. 2007. Locating hybrid individuals in the red wolf (Canis rufus) experimental population area using a spatially targeted sampling strategy and faecal DNA genotyping. Molecular Ecology 16:1823-1843.

Adams, J. R., J. A. Leonard, and L. P. Waits. 2003. Widespread occurrence of a domestic dog mitochondrial DNA haplotype in southeastern US coyotes. Molecular Ecology 12:541-546.

Ames, N. 1982. Mexican wolf recovery plan. Technical report. New Mexico Department of Game and Fish, Albuquerque.

Araiza, M. 2001. Determinación de sitios potenciales para la reintroducción del lobo gris mexicano. MS thesis. Programa Regional de Manejo de Vida Silvestre para Mesoamérica y el Caribe, Universidad Nacional de Costa Rica, Heredia.

Araiza, M., L. Carrillo, R. List, E. Marínez, P. Martínez, O. Moctezuma, N. Sánchez, and J. Servín. 2007. Informe Final del Taller para la 
reintroducción del lobo mexicano (Canis lupus baileyi) en México. El Manzano, Nuevo León, Mexico, March 8-10, 2006. Conservation Breeding Specialist Group, Puebla, Mexico.

Arizona Game and Fish Department, New Mexico Department of Game and Fish, U.S. Department of Agriculture-Animal and Plant Health Inspection Service-Wildlife Services, U.S. Fish and Wildlife Service, and White Mountain Apache Tribe. 2008. Mexican wolf Blue Range reintroduction project interagency field team annual report. Reporting period: January 1-December 31, 2007. Interagency Field Team, Alpine, Arizona. Available from http://www.fws.gov/southwest/es/mexicanwolf/ pdf/Mexican_Wolf_Recovery_Program_Interagency_Field_Team_ Annual_Report_2007.pdf (accessed February 2011).

Arizona Game and Fish Department, New Mexico Department of Game and Fish, U.S. Department of Agriculture-Animal and Plant Health Inspection Service-Wildlife Services, U.S. Fish and Wildlife Service, and White Mountain Apache Tribe. 2009. Mexican wolf Blue Range reintroduction project interagency field team annual report reporting period: January 1-December 31, 2008. Interagency Field Team, Alpine, Arizona. Available from http://www.fws.gov/southwest/es/mexicanwolf/ pdf/MW_2008_Progress_Report_Final.pdf (accessed February 2011).

Berger, J., P. B. Stacey, C. Bellis, and M. P. Johnson. 2001. A mammalian predator-prey imbalance: grizzly bear and wolf extinction affect avian neotropical migrants. Ecological Applications 11:947960.

Bernal Stoopen, J. F., J. M. Packard, and R. Reading. 2009. Mexican wolf recovery: insights from transboundary stakeholders. Pages 115-132 in L. López-Hoffman, E. D. McGovern, R. G. Varady, and K. W. Flessa, editors. Conservation of shared environments: learning from the United States and Mexico. University of Arizona Press. Tucson, Arizona.

Beschta, R. L., and W. J. Ripple. 2010. Mexican wolves, elk, and aspen in Arizona: is there a trophic cascade. Forest Ecology and Management 260:915-922.

Boitani, L. 1983. Wolf and dog competition in Italy. Acta Zool Fennica 174:259-264.

Brown, D. E. 1992. The wolf in the southwest. The University of Arizona Press, Tucson, Arizona.

Brown, J. S, J. W. Laundré, and M. Gurung. 1999. The ecology of fear: optimal foraging, game theory and trophic interactions. Journal of Mammalogy 80:385-399.

Byers, C. R., R. K. Steinhorst, and P. R. Krausman. 1984. Clarification of a technique for analysis of utilization-availability data. Journal of Wildlife Management 48:1050-1053.

Carbyn, L. N. 1982. Coyote population fluctuations and spatial distribution in relation to wolf territories in Riding Mountain National Park, Manitoba. Canadian Field Naturalist 96:176-183.

Carroll, C., M. K. Phillips, C. A. López-González, and N. H. Schumaker. 2006. Defining recovery goals and strategies for endangered species: the wolf as a case study. BioScience 56:25-37.

Ciucci, P., L. Boitani, E. Raganella Pelliccioni, M. Rocco, and I. Guy. 1996. A comparison of scat-analysis methods to assess the diet of the wolf Canis lupus. Wildlife Biology 2:37-47.

Crabtree, R. L., and J. W. Sheldon. 1999. Coyotes and canid coexistence in Yellowstone. Pages 127-163 in T. W. Clark, A. P. Curlee, S. C. Minta, and P. M. Kareiva, editors. Carnivores in ecosystems: the Yellowstone experience. Yale University Press, New Haven, Connecticut.

Dekker, D. 1989. Population fluctuations and spatial relationships among wolves, Canis lupus, coyotes, C. latrans and red foxes, Vulpes vulpes, in Jasper National Park, Alberta. Canadian Field Naturalist 103:261-264.

Fuller, T. K., and L. B. Keith. 1981. Non-overlapping ranges of coyotes and wolves in northeastern Alberta. Journal of Mammalogy 62:403-405.
Gier, H. T. 1975. Ecology and behaviour of the coyote (Canis latrans). Pages 247-262 in M. W. Fox, editor. The wild canids: their systematics, behavioral ecology and evolution. Van Nostrand Reinhold, Toronto.

Hall, E. R. 1980. The mammals of North America. Volume 2. John Wiley and Sons, New York.

Hebblewhite, M., C. A. White, C. G. Nietvelt, J. A. McKenzie, T. E. Hurd, J. M. Fryxell, S. E. Bayley, and P. C. Paquet. 2005. Human activity mediates a trophic cascade caused by wolves. Ecology 86:2135-2144.

Hedrick, P. W., and R. J. Fredrickson. 2008. Captive breeding and the reintroduction of Mexican and red wolves. Molecular Ecology 17:344-350.

Hedrick, P. W., R. N. Lee, and C. Buchanan. 2003. Canine parvovirus enteritis, canine distemper, and major histocompatibility complex genetic variation in Mexican wolves. Journal of Wildlife Diseases 39:909-913.

Hernández, L., and J. W. Laundré. 2005. Foraging in the 'landscape of fear' and its implications for habitat use and diet quality of elk Cervus elaphus and bison Bison bison. Wildlife Biology 11:215-220.

Instituto de Geografía. 2001. Inventario nacional forestal 2000. Instituto Nacional de Geografía Universidad Nacional Autónoma de MéxicoInstituto Nacional de Estadística Geografía e Informática, Mexico City.

INEGI (Instituto Nacional de Estadística Geografía e Informática). 2000. Imagen cartográfica digital 1:250000. Serie II. Datos vectoriales de la carta topográfica, actualizaciones de las vías de transporte desde 1996. INEGI, Aguascalientes, México.

INEGI (Instituto Nacional de Estadística Geografía e Informática). 2002. Localidades de la República Mexicana 2000. Obtenido de principales resultados por .ocalidad. XII censo de población y vivienda 2000. Comisión Nacional para el Conocimiento y Uso de la Biodiversidad (CONABIO) editors., INEGI, México.

INEGI (Instituto Nacional de Estadística Geografía e Informática). 2003. Conjunto de datos vectoriales de la carta de vegetación primaria. Escala 1:1000000 (niveles I y II). INEGI, Aguascalientes, Mexico.

Kaartinen, S., I. Kojola, and A. Colpaert. 2005. Finish wolves avoid roads and settlements. Annales Zoologici Fenici 42:523-532.

Kelly, B. T., P. S. Miller, and U. S. Seal. 1999. Population and habitat viability assessment workshop for the red wolf (Canis rufus). Conservation Breeding Specialist Group (SSC/IUCN), Apple Valley, Minnesota.

Lammertink, J. M., J. A. Rojas Tomé, F. M. Casillas Orona, and R. L. Otto. 1997. Situación y conservación de los bosques antiguos de pinoencino de la Sierra Madre Occidental y sus aves endémicas. Consejo Internacional para la Preservación de las Aves, Sección Mexicana, Mexico City.

Laundré, J. W., L. Hernández, and K. B. Alterdorf. 2001. Wolves, elk, and bison: reestablishing the "landscape of fear" in Yellowstone National Park, U.S.A. Canadian Journal of Zoology 79:1401-1409.

Lehman, N., A. Eisenhawer, K. Hansen, L. D. Mech, R. O. Peterson, P. J. P. Gogan, and R. K. Wayne. 1991. Introgression of coyote mitocondrial DNA into sympatric North American gray wolf populations. Evolution 45:104-119.

Leopold, A. S. 1959. Wildlife of Mexico: the game birds and mammals. University of California Press, Berkeley.

Martínez Gutiérrez, P. G. 2007. Detección de áreas de actividad potenciales para la reintroducción del lobo mexicano (Canis lupus baileyi) en México. MS thesis. Instituto de Ecología, A.C., Xalapa, Veracruz, Mexico.

McBride, R. T. 1980. The Mexican wolf (Canis lupus baileyi): a historical review and observations on its status and distribution. Report. U.S. Fish and Wildlife Service, Albuquerque, New Mexico.

McLaren, B. E., and R. O. Peterson. 1994. Wolves, moose, and tree rings on Isle Royale. Science 266:1555-1558.

Molina Bravo, R. 1964. Control de animales depredadores del ganado en el estado de Sonora. BS thesis. Universidad Nacional Autónoma de México, Mexico City. 
Moreno, J. G., M. D. Matoq, M. S. Roy, E. Geffen, and R. K. Wayne. 1996. Relationships and genetic purity of the endangered Mexican wolf based on analysis of microsatellite loci. Conservation Biology 10:376-389.

Naturalia. 2012. Mensaje de Naturalia, A.C. en relación a la muerte de los lobos liberados en Sonora. Naturalia, Mexico City, Mexico. Available from http://www.naturalia.org.mx/es/otras/noticias.aspx (accessed February 2012).

Neu, C. W., C. R. Byers, and J. M. Peek. 1974. A technique for analysis of utilization availability data. Journal of Wildlife Management 38:541-545.

Nowak, R. M. 1978. Evolution and taxonomy of coyotes and related Canis. Pages 3-16 in M. Bekoff, editor. Coyotes: biology, behavior, and management. Academic Press, New York.

Nowak, R. M. 1983. A perspective on the taxonomy of wolves in North America. Pages 10-19 in L. N. Carbyn, editor. Wolves in Canada and Alaska. Report series 15. Canadian Wildlife Service, Ottawa, Ontario.

Paquet, P. C., J. A. Vucetich, M. K. Phillips, and L. M. Vucetich. 2001. Mexican wolf recovery: three year program review and assessment. Conservation Breeding Specialist Group, Apple Valley, Minnesota.

Parsons, D. R. 2003. Natural history characteristics of focal species in the New Mexico Highlands Wildlands Network. Wildlands Project, Richmond, Vermont.

Randi, E., and V. Lucchini. 2002. Detecting rare introgression of domestic dog genes into wild wolf (Canis lupus) populations by Bayesian admixture analyses of microsatellite variation. Conservation Genetics 3:31-45.

Rhymer, J. M., and D. Simberloff. 1996. Extinction by hybridization and introgression. Annual Review of Ecology and Systematics 27:83-109.

Ripple, W. J., and R. L. Beschta. 2003. Wolf reintroduction, predation risk, and cottonwood recovery in Yellowstone National Park. Forest Ecology and Management 184:299-313.

Ripple, W. J. and E. J. Larsen. 2000. Historic aspen recruitment, elk, and wolves in northern Yellowstone National park, USA. Biological Conservation 95:361-370.

Ripple, W. J., E. J. Larsen, R. A. Renkin, and D. W. Smith. 2001. Trophic cascades among wolves, elk, and aspen on Yellowstone National Park's northern range. Biological Conservation 102:227-234.

Roy, M. S., E. Geffen, D. Smith, E. A. Ostrander, and R. K. Wayne. 1994.
Patterns of differentiation and hybridization in North American wolflike canids, revealed by analysis of microsatellite loci. Molecular Biology and Evolution 11:553-570.

Sánchez, N., and J. A. Guevara. 2006. Evaluación del potencial ecológico del noroeste de México para la reintroducción del lobo mexicano (Canis lupus baileyi). Taller de reintroducción del lobo mexicano (Canis lupus baileyi) en México. Conservation Breeding Specialist Group, Puebla, Mexico.

Secretaría del Medio Ambiente y Recursos Naturales (SEMARNAT). 2010. NORMA Oficial Mexicana NOM-059-SEMARNAT-2010. Protección ambiental-Especies nativas de México de flora y fauna silvestres-Categorías de riesgo y especificaciones para su inclusión, exclusión o cambio-Lista de especies en riesgo. Diario Oficial de la Federación 30-12-2010.

Soulé, M. E., J. A. Estes, J. Berger, and C. Martínez del Río. 2003. Ecological effectiveness: conservation goals for interactive species. Conservation Biology 17:1238-1250.

Soulé, M. E., J. A. Estes, B. Miller, and D. L. Honnold. 2005. Strongly interacting species: conservation policy, management, and ethics. BioScience 55:168-176.

Subcomité Técnico Consultivo para la Recuperación del Lobo Mexicano, Universidad Juárez del Estado de Durango, Universidad Nacional Autónoma de México, Universidad Autónoma Metropolitana, Universidad Autónoma de Nuevo León, Universidad Autónoma de Querétaro- Centro de Investigación en Alimentación y Desarrollo, Ovis, and Naturalia. 2009. Proyecto CONANP/DAJ/CC/09 de seis estudios técnicos de la disponibilidad de presas y de diagnóstico de la percepción y de viabilidad social en los sitios potenciales identificados para la reintroducción del lobo Mexicano en los estados de Sonora, Chihuahua, Durango, Coahuila, Nuevo León y Zacatecas. Comisión Nacional de Áreas Naturales Protegidas, México, D. F.

Verardi, A., V. Lucchini, and E. Randi. 2006. Detecting introgressive hybridization between free-ranging domestic dogs and wild wolves (Canis lupus) by admixture linkage disequilibrium analysis. Molecular Ecology 15:2845-2855.

Vilà, C., et al. 2003. Combined use of maternal, paternal and bi-parental genetic markers for the identification of wolf-dog hybrids. Heredity 90:17-24.

Whittington, J., C. Cassady St. Clair, and G. Mercer. 2005. Spatial responses of wolves to roads and trails in mountain valleys. Ecological Applications 15:543-553.

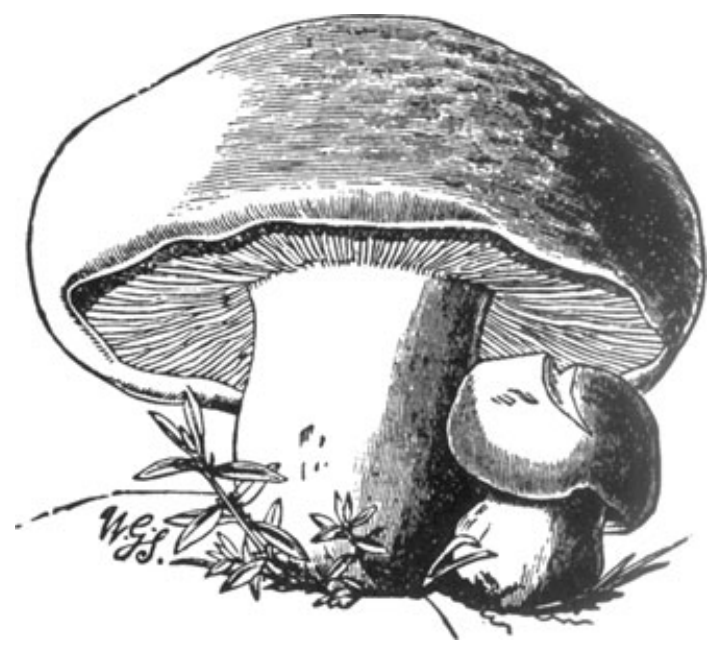

